\title{
A Desire for the Marsupial Space: A Lacanian Reading of Lacan
}

\author{
Mehdi Aghamohammadi \\ Department of English Language and Literature, Azarbaijan Shahid Madani University, Iran \\ E-mail: mrmehdi.ir@gmail.com
}

Doi:10.7575/aiac.alls.v.8n.1p.111

URL: http://dx.doi.org/10.7575/aiac.alls.v.8n.1p.111
Received: 04/10/2016

Accepted: 17/01/2017

\begin{abstract}
Jacques Lacan is regarded as an influential French psychoanalyst in the 20th century. In the present article, first, a brief biography of this interpreter of Sigmund Freud is presented and then his key psychoanalytic theories, largely about the infant-mother-father relationship, are summarized. These data are finally analyzed mainly according to Lacan's own ideas. In other words, this article is aimed at providing a Lacanian reading of Lacan. It reveals that his family in particular had a huge impact on his theories, which strongly reflect Lacan's desire for his mother, specifically her marsupial space. The article is concluded by exploring a quatrain by the famous Persian poet Jalal ad-Din Mohammad Rumi in order to further substantiate the claim about Lacan's desire for the space through theorization.
\end{abstract}

Keywords: Lacan, Mother, Rumi, Marsupial Space

\section{Introduction}

Before offering a Lacanian reading of Jacques Lacan, the article is going to give a concise overview of psychoanalysis and expand on the psychoanalytic significance of infancy and childhood. Next, a brief biography of the influential French psychoanalyst is provided. The main focus of the article is infancy and childhood, due to which the article spotlights these periods in Lacan's biography. Nevertheless, particular events in his adulthood, up to the age of 32, are also touched on so as to add more details to the discussion. Afterwards, main relevant theories of this interpreter of Sigmund Freud, largely about the infant-mother-father relationship, are explored. The article then applies the Lacanian theories to the analysis of the biography. Finally, its reference to a quatrain by the distinguished Persian poet Jalal adDin Mohammad Rumi attempts to reinforce the conclusion of the study.

\section{Psychoanalysis, Infancy, and Childhood}

There are numerous approaches to exploring the human condition. One of them is psychoanalysis, which investigates human behavior and its underlying motivations and attempts to devise methods for treating mental disorders. Its unique task is to impart knowledge largely about the unconscious and unconscious processes as regulators of behavior. In fact, psychoanalysis is intended to uncover truths about the human. However, this never means that it holds a monopoly of truth about human existence (Karlsson, 2010, p. 162).

As a method, psychoanalysis was first used by the Austrian neurologist Sigmund Freud (1856-1939) to treat psychological and emotional disorders. The analysand, during this form of therapy, is encouraged to talk freely about his dreams and childhood experiences (Bressler, 2007, p. 357). Hence, the early part of a human's life is of profound significance to a psychoanalyst. Due to this, the present article will basically revolve around the psychoanalysis of infancy and childhood.

Before birth, the infant is a fetus contained in the uterus inside the mother's body. Only a minimal degree of movement is possible for it. The fetus accompanies the mother as she moves in her external space. After birth, the infant lives in a uterine state created by the mother through her support and care. The infant's present space, in the breast area, called the "marsupial space," is now wider than the uterine space and he is much freer than before. Now, he can move in the mother's external space. As he grows up, his personal space grows wider until it coincides with the maternal space and, later, with the general space, where the subject becomes an object among other objects. Simultaneously with this physical process, "a space internal to the subject is formed where psychic internal objects live in intrapsychic relationships. They are experienced very concretely at first, for example, as sensations or elaborated perceptions and even more elaborated later as representations of a very complex nature" (Rey, 1988, pp. 212-213). In fact, as infants, we dwell in the mother's physical, mental, and emotional space.

\section{Jacques Lacan}

\subsection{A Brief Biography}

As one of the most famous psychoanalysts, Jacques-Marie Émile Lacan (1901-1981) is considered part of the holy trinity of postmodernism, along with Michel Foucault (1926-1984) and Jacques Derrida (1930-2004) (Kotsko, 2008, p. 77). Lacan reinterpreted Freudian theories in structuralist and poststructuralist terms (Moreno, 2014, pp. 127-128). 
Jacques Lacan was born in 1901. Jacques was the first child of Alfred Lacan (1873-1960) and Emilie Baudry (18761948). In 1902, Raymond, a brother, was born but died of hepatitis two years later. In 1903, Magdeleine-Marie, a sister, was born. In 1908, another brother, Marc-Marie, was born. Jacques had a special relationship with his brother, whom he called "Marco" and to whom he acted very fatherly. Jacques's family was a middle-class Catholic family. His father's religious faith was not deep; in contrast, his mother was a faithful Christian, with a mystic streak. Emilie not only raised children but also helped Alfred in his business. It must be mentioned that Alfred was a stingy father. Jacques's memory of his childhood in this family was terrifying. He loathed his paternal grandfather, Émile, who behaved tyrannically toward Alfred and Jacques. Émile's impact on Jacques's "name-of-the-father" is considered to have been more than Alfred's. During 1917-1918, Jacques was considerably influenced by philosophical writings of Spinoza. In the First World War (1914-1918), the college where he received his secondary education was partially used as a military hospital, which must have been a motivation for his pursuit of medicine, against his father's advice. Undoubtedly, the sight of wounded soldiers with missing or amputated limbs had a traumatic effect on Jacques at this age. After a short stay in the military, he was discharged in 1921 due to his thinness. In 1929, Marco joined the Benedictine monastery in spite of the fact that Jacques was against it. Reinforced by writings of Nietzsche, Jacques had already rejected his religious faith. By 1932, his profound knowledge of psychiatry and philosophy had led him to the synthesizing of Freud's teachings, clinical psychiatry, and Surrealism. In 1932, he obtained Doctorat d'État in psychiatry (Roudinesco, 1990, pp. 103-104; Giraldo, 2012, pp. 4-5).

\subsection{Psychoanalysis}

In Lacan's view, as an autonomous discipline, psychoanalysis is no branch of psychology, medicine, philosophy, or linguistics. It aims to articulate truth rather than cure. For him, psychoanalytic theory is not a religious but scientific mode of discourse (Evans, 2006, p. 155). It must be remarked that his psychoanalysis is positioned somewhere between literature and science (Clemens, 2013, p. 56). In addition, Lacanian psychoanalysis is not "a discourse of mastery wherein the analyst is considered some sort of master of reality." In fact, in the course of the analysis, "the analyst does not learn what is real and what is not, but learns something about his or her own fantasy (even as it is reconfigured) and how to prevent it from impinging on work with patients" (Fink, 1999, p. 245, note 8). Additionally, Lacan was in favor of science, which he aligned with psychoanalysis. Furthermore, for him, psychoanalysis was a theory that linked three dimensions - namely the symbolic, the imaginary, and the real - and uncovered the relationship between them (Lin, 2007, p. 4).

In Lacan's view, the human psyche is comprised of three orders, i.e. parts or registers, namely imaginary, symbolic, and real, which interact with each other; in fact, no order is left behind after entering the other. For Lacan, these orders shape human behavior. The first two orders are of considerable significance for the way the infant's psyche is developed and shaped. The first order is a repository of our fantasies, wishes, and images. During the imaginary order, from the infant's birth until around the 6th month, the mother and the infant are symbiotically related to each other. The mother dominates the first order. This order is also called the prelinguistic or preverbal order. In this order, the infant entirely depends on the mother, who provides him with peace and security. He feels unified with objects, toys, and his mother's body, as images, in the imaginary order, which is the order of images, i.e. representations. Closely tied to this order is the mirror stage, at which the child is around 6-18 months of age. At this stage, which is, in fact, the latter phase of development in the first order, the child is able to recognize himself in a mirror or anything inducing apperception. During the mirror stage, the child becomes aware that he is an independent being and separate from the mother. Prior to this stage, the child experienced his body as fragmented and shapeless but now he has a sense of cohesion, completeness, and oneness with the world. However, this sense is illusive because he is not in full control of himself and the self reflected in the mirror is not his true self. Gradually, the child is going to feel alienated from his mother, thereby craving for the unification with her. This loss, or lack, and desire will be with him forever. The rest of his life will be a struggle for satisfying this desire by picking a substitute for the lost object. However, the desire will be unfulfilled and will lead to a new lack and new desire. In other words, searching for the mother, the (primordial) Other, the child will resort to endless numbers of others, i.e. objects, none of which is found to be the Other at all. These objects are called "objet petit a." In the second order, dominated by the father, the child learns language, begins to speak, and socialize. The father represents authority, laws, and social norms. The father stands between the mother and the child, who has to obey rules and norms out of fear of being symbolically castrated by the father. The father's presence intensifies the child's alienation and separation from the mother. In the symbolic order, the child's self is shaped with regard to a powerful Other, who keeps threatening, controlling, monitoring, and objectifying him. Language shapes the child's psyche and identity as a separate being. He discriminates between individual words and vowels on the basis of difference. Through differences and similarities, his identity is shaped. He becomes aware that his identity is different from other identities. The illusion of completeness which appeared in the first order disappears in the symbolic order. It should be remembered that, for Lacan, the unconscious does not exist prior to the entry into the realm of language. Rather, it is formed with the appearance of language. Due to this, it is only through language that the unconscious becomes available to a therapist or psychoanalyst (Moreno, 2014, pp. 128-129; Bressler, 2007, pp. 153155). Indeed, for Lacan, language "designates not simply verbal speech or written text but any signifying system that is based upon differential relations" (Homer, 2005, p. 69). In other words, "language is not a system of signs (as it was for Saussure) but a system of signifiers." As basic units of language, signifiers can be reduced to differential elements. They are also combined in signifying chains based on laws of metonymy (Evans, 2006, p. 189).

Lacan emphasized "the primacy of language in revealing the unconscious" (Lechte, 2003, p. 212) and proposed some different definitions of the unconscious, including, "The unconscious as a gap or rupture"; "The unconscious as 
structured like a language"; and "The unconscious as the discourse of the Other." The second definition, declared under the influence of structuralism, is deemed to be this French psychoanalyst's fundamental thesis and most significant contribution to not only psychoanalysis but also literary studies (Homer, 2005, pp. $66 \& 68$ ).

For Lacan, the symbolic is the realm of not only law and norms but also difference, language, and particularly metonymy (Steinmetz, 2007, p. 57). It must be mentioned that, influenced by the Russian-born American linguist Roman Jakobson (1896-1982), Lacan equated metaphor and metonymy, as two basic linguistic processes, respectively, with "displacement" and "condensation," two unconscious processes, introduced by Freud (Lechte, 2003, p. 212). The real order is considered the most complex in Lacan's system. There are arguments over whether it represents the period following the symbolic order or prior to the imaginary order. Furthermore, critics' descriptions of this order differ greatly. It could be said that the real is a state of existence occurring during the first few months of an infant's life. At this stage of life, no conception of language or the outside world does the infant have. Nevertheless, what he experiences is an unlimited number of sensations of need, for example, need for sleep and food. The truth about this order is that it is extremely elusive. The point is that, by applying words, i.e. language, to describe it, we leave the real and enter the symbolic and, since our understanding of it fails, a sense of trauma and anxiety inflicts us. The real remains elusive unless we return to a prelinguistic state (Etherington-Wright \& Doughty, 2011, p. 144). For Lacan, language is regarded as the locus of "all the rules and customs of a society" (Segal, 2002, p. 201). Moreover, as mentioned before, it is through language that the child enters the social world. As a result, the more we undermine the dominance of language and the more detached we become from social norms and conventions, the farther from the symbolic and the closer to the real we will be. However, as stated above, any exposure to or contact with the real leads to trauma.

Lacan's theory of the human psyche is rife with fragmentation, lack, and loss. The self that is the outcome of this theory is an alienated and divided one. In his opinion, our desire, through literary texts, is momentarily gratified due to an instantaneous return to the imaginary order and a sensation of the pure joy of unification with our mothers. He calls this joy "jouissance" (Bressler, 2007, p. 155). Lacan calls the return of jouissance repetition. For him, repetition is the "insistence" of the signifier. There are some signifiers which insist on returning in the subject's life in spite of the fact that some resistances block them. Lacan asserts that jouissance is better described as "painful pleasure" deriving from satisfaction. In other words, jouissance is an excess of enjoyment or pleasure which returns repeatedly and goes beyond the limits of the "pleasure principle." This transgression does not lead to more pleasure but pain and suffering, i.e. jouissance (Evens, 2006, pp. $167 \&$ 93).

Lacan identified three forms of jouissance: phallic jouissance, the jouissance of the Other, and joui-sens. Phallic jouissance pertains to the Name-of-the-Father, i.e. phallus. The father himself enjoys it but prohibits the child from enjoying it. The jouissance of the Other is related to the object, mainly the phallus, the child assumes, satisfies the mother's desires. As for the third form, Lacan puns on the sound of the word jouissance. Joui-sens suggests "enjoyment-in-sense" or "enjoyment-in-meaning." It refers to the ambiguity of the Other's desire, resulting from the answer to "what does the Other want?" (Willet, 2007, pp. 16-17).

The child desires to attain jouissance and enjoy the mother's body. However, the father erects a barrier (Mieli, 2000 , p. 269). It must be remembered that, opposing the tendency of placing the dual relation of the mother and the child at the heart of psychoanalytic theory, Lacan stressed the role of the father, who intrudes into the relation. Therefore, for Lacan, the father is more than a rival to the child for the mother's love. It is through the father that the child enters the social order. The father's absence is a key factor behind all psychopathological structures. For Lacan, the mother is "an engulfing force which threatens to devour the child." The child's failure to get detached from her results in phobia, perversion, or any other peculiarity (Evans, 2006, pp. 62 \& 120).

Describing the role of the symbolic father, i.e. father in the symbolic order, Lacan introduced his theory of "Le Nom-duPère" (French, "the Name-of-the-Father"), a symbolic function intruding into the child's illusory world and breaking the imaginary dyad of the child and the mother. The child realizes that father is the one that fulfills the mother's desire and is in possession of the phallus. This leads to the substitution of the desire-of-the-mother for the Name-of-the-Father. As a result, the child's entry into the symbolic order is with a lack (Homer, 2005, pp. 55-56). It must be noted that the desire of the mother is a double genitive which refers to both the mother's desire and the desire for the mother. First, the child has the assumption that he is all that the mother desires; psychologically, he becomes the phallus for the mother. Second, the child himself desires the mother (Hecq, 2015, p. 95).

Lacan puns on the sound of French phrase "Le Nom-du-Père" ("the Name-of-the-Father" or "the Name-of-God"), which is pronounced like les nons du père ("the father's no's") and les non-dupes errent ("non-dupes err"). Le Nom-duPère connotes patriarchy and legislation. Moreover, "Father" could signify the Author of the Law. Similarly, les nons du père refers to the father's/Father's prohibitions and, therefore, law/Law. In the phrase les non-dupes errent, "nondupes" is substituted for the "father"/"Father" and, as compared with the second phrase, errancy is substituted for the "no’s" (Johnson, 2010, p. 69; Sheridan, 2005, p. xi; Regnault, 1995, p. 65).

An infant is born in a state of helplessness and is incapable of satisfying his own needs. Thus, he depends on the Other to help him satisfy them. In order to receive the Other's help, the infant must express his needs vocally. Lacan calls the infant's cry to the mother "the call." In Lacan's opinion, these screams or cries are not mere instinctual signals. They are organized in a linguistic structure prior to the child's capability to articulate recognizable words. A scream articulates fear, hunger, loneliness, or something else; however, the mother interprets, produces, or, in Lacan's terminology, "punctuates" the meaning. From this perspective, it is the mother that introduces the child into language 
by her interpretations. "One common misconception of Lacan is that language is synonymous with the symbolic order. This is, however, not correct; Lacan argues that language has both a symbolic and an imaginary dimension" (Evans, 2006 , pp. $38,35,159,121, \& 100)$.

\section{Theory: Lacan's Marsupial Space}

Above, a short biography of Lacan was provided and his key theories, mainly about the infant-mother-father relationship, were briefly studied. Now, I am going to analyze the biography according to the above-mentioned Lacanian theories.

\subsection{Lacan's Mother: Her Faith}

As stated before, any human is always in pursuit of unification with the mother. Thus, Lacan also had this desire. Lacan's mother was a faithful Christian. However, Lacan gradually lost his faith and became an atheist. Hence, the mother had something that he lacked. In other words, Lacan lost not only his mother but also his faith, a motherly quality. In my opinion, his desire to return to the mother coupled with a desire for faith, among other things, which the mother had. As a result, Lacan was under the influence of this motherly desire, which impacted on his theories unconsciously. For instance, in his "Name-of-the-Father," one of the puns refers to Father, i.e. God. The permeation of a religious discourse from such examples implies that he was affected by his mother's desire and looped back to it.

Another example is that the way he theorized about the human psyche resembles prophets' ways. A prophet appeared among people and gave them a speech. He initially spoke about lucid things but, gradually, grew abstruse, for example, as he discussed the existence of the other world or Doomsday. Similarly, Lacan's work was "essentially oral in nature" (Roudinesco, 2001, p. 89). In addition, Lacan's descriptions of the first two orders are quite intelligible; however, his real order is as elusive as the afterlife. These show that Lacan's approach was unconsciously affected by a religious archetype. Additionally, Lacan's theories are interpretable — so were prophets' messages.

\subsection{Lacan's Mother: His Theories}

Other examples could be found among his theories revealing Lacan's desire to be back to the mother. For instance, Lacan insisted that "[objet petit a] should remain untranslated" (Evans, 2006, p. 128). In my opinion, his insistence on keeping the phrase in his mother language, French, is an unconscious attempt to maintain maternity in his theory, which implies a desire for the mother. Moreover, it is said that he "spoke/wrote only in French" (Bond, 2009, p. 33).

Another example: Lacan frequently modified his ideas. For instance, his position on the nature of language underwent a lengthy process of development. He also changed his definition of jouissance over time (Bernstein, 2012, p. 233). In addition, from 1971 on, his style grew "more densely populated with puns and neologisms" (Evans, 2006, pp. 99 \& 100). Furthermore, some people consider Lacan's oeuvre abstruse and say that "his murky formulations are impenetrable" (Fink, 2004, p. viii). Although this abstruseness could partially pertain to imprecise translations, I think the oeuvre is itself largely abstruse. For instance, I could refer to two distinct interpretations of one Lacanian theory: "Whereas Kristeva argues that Lacan makes desire operate according to the logic of metonymy and overlooks the metaphoric operations of love, Irigaray argues that Lacan makes desire operate according to a logic of metaphoric substitution and overlooks the metonymic operations of a true bisexuality" (Oliver, 2016, p. 171). Definitely, modifications, puns, neologisms, and abstruseness render Lacan interpretable. Whether he grew interpretable or tried to be interpretable, his oeuvre carries readers' interpretations. I relate the crawl of interpretations across his oeuvre to the unconscious impact of his mother's interpretations of his infancy calls on him, whose ideas sprang from his desiringfor-the-mother brain. To understand this process better, we could remember how, while dreaming, the brain brings together bulks of diverse fragmentary images and experiences to create a novel story in a dream.

One more example about the way Lacan's theorization was affected by his desire for his mother: From 1971 on, Lacan emphasized "the poetry and ambiguity of language." As mentioned above, his style also became "ever more densely populated with puns and neologisms" (Evans, 2006, p. 100). In my opinion, Lacan's use of puns is a sign of his desire to be one with the mother in that a pun collects distinct meanings in one word or one sound. In other words, his separation from his mother has turned into a fixation which leaks out through his theories, for instance, in the form of puns.

\subsection{Lacan's Mother: A Supportive Wife}

As stated above, Lacan's Mother helped Alfred in his business, which suggests that this faithful lady was also supportive to his husband, who had a major role in Jacques's entry into the symbolic order. Surely, Jacques shared this trait his mother possessed and, therefore, unconsciously, contributed to the order of Law, language, norms, and socialization. For example, he criticized the way other forms of psychoanalysis tended to minimize the significance of language and stressed the analysand's body language, for example, at the expense of the analysand's speech (Evans, 2006, p. 100).

\subsection{Lacan's Father and Grandfather: His Theories}

It was mentioned earlier that Lacan's father and grandfather impacted on his formation of the "Name-of-the-Father."

\subsection{Lacan's Father: His Faith}

Lacan's father did not have deep religious faith. Moreover, as indicated before, the paternal dominance impacted on Jacques's life. I consider this a major factor behind Jacques's atheism. In a seminar entitled "Identification" (19611962), he violently attacked Émile and declared that he was "that horrible character to whom I owe my precocious 
arrival at the fundamental function of cursing God" (as cited in Roudinesco, 2001, p. 95). Although an atheist, Lacan thought, "God is unconscious," rather than "dead." He regarded this as the true formula of atheism (Evans, 2006, p. 166). By "God is unconscious," Lacan meant that the subject believes in God in his unconscious even though he consciously says that He is dead and does not exist.

\subsection{Lacan's Father: Revolt}

Jacques was not interested in his father's business and pursued medicine, against his father's advice. This is an example of his revolt against the father-in my opinion, a sign of desire for the mother. His father "never recognized him for what he was: an intellectual disconnected from his original environment and thus from any interest in the business of selling vinegars or mustards." He always suffered this (Roudinesco, 2001, p. 95).

Interestingly enough, when Marco was joining the Benedictine monastery, Jacques, who behaved fatherly toward him, was against it. However, Marco did not follow his advice. This was Marco's revolt against a fatherly image. I think such experiences intensified Lacan's revolt against the father, i.e. rules, for examples, particularly rules of language, through neologisms, for instance. All of these contributed to his desire for the mother.

We can also have a different perspective. As mentioned earlier, the father plays a positive role in saving the child from the mother's "engulfing force." According to this, since Émile behaved tyrannically toward Alfred, together with Jacques, Jacques's desire for the mother, I think, was accompanied/replaced here by a defense of Alfred, as a savior, (whom also the mother helped), against Émile, as a punisher. It could be said that Jacques's hatred for Émile had been substituted for his jealousy of Alfred.

\subsection{Other Family Members of Jacques Lacan}

Jacques lost his first brother in infancy. Naturally, afterwards, his mother paid a lot more attention to Jacques as a child and caressed and stroked him much more. In fact, the tragic event had intensified her desire for the living child. Simultaneously, the child's desire for the mother also increased, particularly due to the failure of an "intrusion complex." According to Lacan, there are three "family complexes." Each of them is the trace of a "psychical crisis" accompanying a "life crisis." The first one is the "weaning complex," which is the interruption of a biological relation. The child experiences the second one, "intrusion complex," when he comes to the realization that he has siblings. The final complex is the "Oedipus complex" (Evans, 2006, p. 28). Therefore, Jacques's marsupial space was wider and safer. Even when a sister was born, she could not be substituted for him because Jacques was male, i.e. a phallic image. (I explored the relationship between Jacques and his second brother above.) As Jacques grew up, he fell much further away from the marsupial space. At the same time, when he was an adolescent, for example, he entered other spaces. It should be noted that adolescence is "a time during which great a different set of spatial relationships emerge" (Croft, 2006, p. 209). However, his desire for the marsupial space never disappeared rather became much more than ever.

\subsection{Lacan: Social Institutions}

The military is an important social institution. Lacan's discharge from it, I think, was an opportunity for him to escape the engulfment of one paternal swamp, which could have fuelled his desire for the mother. Moreover, in my opinion, his memories of wounded soldiers and the outcome of war had revealed to him horrors of the (non-marsupial) world, which had too stimulated his desire for the marsupial space.

\subsection{Lacan: Literature}

According to Lacan, one can find moments of jouissance through literature, particularly in the writings of James Joyce, William Shakespeare, and Edgar Allan Poe (Bressler, 2007, p. 155). I assume that Lacan's references and allusions to literature, even through examples and literary techniques such as metonymy and metaphor, are signs of his desire for the marsupial desire. In other words, by theorizing about literature and drawing on literary terms and techniques, this defender of the scientific mode of discourse was, in fact, unconsciously satisfying a desire. Moreover, in my opinion, there is a relationship between his atheism and his turn to literature, which reminds me of Matthew Arnold (1822-1988), a British poet and critic, and similar figures. Modernist poets and critics worrying about "the effects of secularization often turned to poetry as an alternative to religion" (Lewis, 2006, p. 20). For instance, Arnold in 1880 asserted, "Without poetry, our science will appear incomplete; and most of what now passes with us for religion and philosophy will be replaced by poetry" (2000, p. 7). As a result, I think Lacan had similarly substituted literature for religion and tried his best to fill in pertinent gaps in an unconscious way.

Based on these points and examples, which offered a Lacanian reading of Lacan, I believe that Jacques Lacan's family had a profound impact on his theories, which strongly reflect Lacan's desire for his mother, especially her marsupial space. In the following section of the article, I am going to expand on a quatrain by the renowned Persian poet Rumi so as to strengthen the conclusion that Lacan desired his mother and the marsupial space.

\section{A Rumian Reading of the Lacanian Reading}

Molana Jalal ad-Din Mohammad, also known as Rumi or Molavi, (1207-1273), was a distinguished Persian poet, mystic, and preacher. Rumi's central thesis was that humankind has an origin which is the genesis of unity and integrity; however, in this world of plurality and multiplicity, (s)he has fallen far away from it and whatever (s)he does is intended to return to that origin (Sharifi, 2008, p. 1368). His Divan-e Shams-e Tabrizi (Persian, "Divan of Shams Tabrizi"), also entitled Kolliyat-e Shams (Persian, "Poetry collection of Shams") or "Divan-e kabir ( Persian, "Great divan"), is a poetry collection with around 42,000 couplets. This work reveals the spiritual relationship between Rumi 
and his spiritual mentor, Shams Tabrizi, whom Rumi adored so much that he wrote most of the poems for him. The divan includes various poetic forms, one of which is quatrain. In Quatrain 1864, Rumi writes:

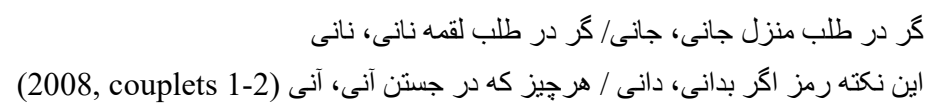

My translation of the quatrain reads as follows:

If you are in pursuit of the beloved's home, you are the beloved.

If you are in pursuit of a morsel of bread, you are bread.

If you understand this enigma, you will understand

You are whatever you are in search of.

The last line of the quatrain is the focus of the present article. According to the line, the dominant desire in a desirer turns the desirer into the desired one, which means the overwhelming desire for something is manifested in the desirer's body and soul. In my opinion, the sunflower analogy could fit here. This plant has a round floral head resembling the sun. This tall plant turns toward the sun as it appears in the sky in the East and the flower pursues it until the sun sets in the West. According to Rumi's philosophy, one could say this flower desires the sun and therefore not only its appearance but also its name shows that its desired one is the sun. According to this, I believe that Lacan's desire for the mother and the marsupial space was manifested in him and permeated through his theories and ideas. It must be noted that this Rumian reading of my Lacanian reading of Lacan is consistent with Lacan's attachment of significance to literature.

\section{Conclusion}

The present article aimed to introduce a Lacanian reading of Jacques Lacan. To this end, it first provided a brief introduction to psychoanalysis and highlighted the psychoanalytic significance lying in infancy and childhood. Then, it gave a short biography of Lacan. Since the focus of the article was infancy and childhood, these periods were included in the biography. However, certain events in his adulthood, up to the age of 32, were also described so as to flesh out the discussion. Next, his main theories, primarily about the infant-mother-father relationship, were studied. The article finally drew on the Lacanian theories and analyzed the biography. The overall result was that, apart from social events, his family, especially his parents and paternal grandfather, had a pronounced effect on his theories both directly and indirectly. It was simultaneously concluded that whatever Lacan theorized was fundamentally an unconscious attempt to go back to his mother, particularly her marsupial space. In other words, Lacan's theories reflect his desire for the marsupial space. To reinforce this conclusion and substantiate the manifestation of the return in Lacan's theories, a quatrain by Rumi was investigated. According to the Persian poem, the most powerful desire in a desirer changes the desirer into the desired one; in other words, an irresistible desire for something is manifested in the desirer's physical structure, appearance, character, thoughts, words, and feelings.

\section{References}

Arnold, M. (2000). The study of poetry. In R. Detweiler \& D. Jasper (Eds.), Religion and literature: A reader (p. 7). Louisville: Westminster John Knox Press.

Baldick, C. (2008). The Oxford dictionary of literary terms. Oxford: Oxford University Press.

Bernstein, J. W. (2012). Jacques Lacan. In G. O. Gabbard, B. E. Litowitz, \& P. Williams (Eds.), Textbook of psychoanalysis (2nd ed., pp. 225-238). Washington: American Psychiatric Publishing.

Bond, H. (2009). Lacan at the scene. Massachusetts: The MIT Press.

Bressler, C. E. (2007). Literary criticism: An introduction to theory and practice (4th ed.). New Jersey: Pearson.

Clemens, J. (2013). Psychoanalysis is an antiphilosophy. Edinburgh: Edinburgh University Press.

Croft, J. (2006). A life of longing behind the bedroom door: Adolescent space and the makings of private identity. In G. Smyth \& J. Croft (Eds.), Our house: The representation of domestic space in modern culture (pp. 209-226). Amsterdam: Rodopi.

Etherington-Wright, C., \& Doughty, R. (2011). Understanding film theory. New York: Palgrave Macmillan.

Evans, D. (2006). An introductory dictionary of Lacanian psychoanalysis. New York: Routledge.

Fink, B. (1999). A clinical introduction to Lacanian psychoanalysis: Theory and technique. Cambridge: Harvard University Press.

---. (2004). Lacan to the letter: Reading écrits closely. Minneapolis: University or Minneapolis.

Giraldo, M. (2012). The dialogues in and of the group: Lacanian perspectives on the psychoanalytic group. London: Karnac Books. 
Hecq, D. (2015). Towards a poetics of creative writing. Bristol: Multilingual Matters.

Homer, S. (2005). Jacques Lacan. New York: Routledge.

Johnson, B. (2010). Moses and multiculturalism. California: University of California Press.

Karlsson, G. (2010). Psychoanalysis in a new light. Cambridge: Cambridge University Press.

Kotsko, A. (2008). Žižek and theology. New York: T\&T Clark.

Lechte, J. (2003). Key contemporary concepts: From abjection to Zeno's paradox. London: SAGE Publications.

Lewis, P. (2006). Religion. In D. Bradshaw \& K. J. H. Dettmar (Eds.), A companion to modernist literature and culture (pp. 19-28). Malden: Blackwell Publishing.

Lin, K. M. (2007). The Lacanian spectator: Lacanian psychoanalysis and the cinema. (Doctoral dissertation, University of Massachusetts Amherst). Retrieved from http://scholarworks.umass.edu/dissertations/AAI3275744

Mieli, P. (2000). Femininity and the limits of theory. In K. R. Malone \& S. R. Friedlander (Eds.), The subject of Lacan: A Lacanian reader for psychologists (pp. 265-278). New York: State University of New York Press.

Molana Jalal ad-Din Mohammad. (2008). Roba'i 1864 [Quatrain 1864]. In Molana Jalal ad-Din Mohammad, Kolliyat-e Shams, ya, divan-e kabir [Poetry collection of Shams, or, great divan] (4th ed., Vol. 8, p. 313). (B. Foroozanfar, Rev.). Tehran: Amir Kabir Publications. [Persian]

Moreno, M. C. (2014). Critical approaches to Shakespeare: Shakespeare for all time. Madrid: Universidad Nacional de Eduation a Distancia.

Oliver, K. (2016). Womanizing Nietzsche: Philosophy's relation to the “feminine." New York: Routledge.

Regnault, F. (1995). The name-of-the-father. In R. Feldstein, B. Fink, \& M. Jaanus (Eds.), Reading seminar xi: Lacan's four fundamental concepts of psychoanalysis (pp. 65-76). Albany: State University of New York Press.

Rey, J. H. (1988). Schizoid phenomena in the borderline. In E. B. Spillius (Ed.), Melanie Klein today. Developments in theory and practice. Volume I: Mainly theory (pp. 197-223). New York: Routledge.

Roudinesco, É. (1990). Jacques Lacan \& co: A history of psychoanalysis in France, 1925-1985. (J. Mehlman, Trans.). Chicago: The University of Chicago Press.

---. (2001). Jacques Lacan, or the erasure of history. In S. Lotringer \& S. Cohen (Eds.), French theory in America (pp. 87-98). New York: Routledge.

Segal, L. (2002). Sexualities. In K. Woodward (Ed.), Identity and difference (pp. 183-238). California: SAGE Publications.

Sharifi, M. (2008). Farhang-e adabiyyat-e Farsi [Dictionary of Persian literature] (2nd ed.). (M. R. Jafari, Ed.). Tehran: Farhang-e Nashr-e No' \& Mo'in Publications. [Persian]

Sheridan, A. (2005). Translator's note. In J. Lacan, Écrits: A selection (pp. viii-xi). (A. Sheridan, Trans.). New York: Routledge.

Steinmetz, G. (2007). The Devil's handwriting: Precoloniality and the German colonial state in Qingdao, Samoa, and Southwest Africa. Chicago: The University of Chicago Press.

Willet, E. K. (2007). Music as sinthome: Joy riding with Lacan, Lynch, and Beethoven beyond postmodernism. (Doctoral dissertation, The University of Texas at Austin). Retrieved from http://hdl.handle.net/2152/3231 